\title{
Vietnam's Industrialization Ambitions: The Case of Vingroup and the Automotive Industry
}

By Le Hong Hiep

\section{EXECUTIVE SUMMARY}

- Vietnam has officially admitted its failure to achieve industrialized economy status by 2020. This failure is partly due to its inability to grow a strong local manufacturing base and develop key strategic industries.

- The participation of Vingroup, the country's largest private conglomerate, in the automotive industry has sparked new hopes for Vietnam's industrialization drive. The company, through its subsidiary Vinfast, aims to become a leading automaker in Southeast Asia with an annual capacity of 500,000 units and a localization ratio of 60 per cent by 2025 .

- Challenges that Vinfast faces include its unproven track record in the industry; the limited size of the national car market; the lack of infrastructure to support car usage in Vietnam; the intense competition from foreign brands; and its initial reliance on imported technologies and know-hows.

- However, Vinfast enjoys certain advantages in the domestic market, including the large potential of the Vietnamese automotive market; its freedom as a new automaker to define its business strategies without having to deal with legacy issues; Vingroup's sound business and financial performance and its ecosystem; strong support from the Vietnamese government; and nationalist sentiments that will encourage certain Vietnamese customers to choose its products. 
- If Vinfast is successful, it will boost Vietnam's GDP growth and reinvent the country's automotive industry. Its success will also contribute significantly to the realization of Vietnam's industrialization ambitions and bring private actors into the centre stage of the economy. If the company fails, however, it will cause considerable problems for both Vingroup and the Vietnamese economy. 


\section{Vietnam's Industrialization Ambitions: The Case of Vingroup and the Automotive Industry}

By Le Hong Hiep ${ }^{1}$

\section{INTRODUCTION}

At its eighth national congress in 1996, the Communist Party of Vietnam (CPV) set the target of turning Vietnam into an industrialized economy by 2020. However, in April 2016, National Assembly Chairwoman Nguyen Thi Kim Ngan acknowledged that Vietnam would not be able to achieve that goal. Documents of the CPV's twelfth national congress in January 2016 also acknowledged this failure. Specifically, the political report of the congress replaced the target of "creating foundations to turn the country into a basically modern and industrialized country by 2020 " in the eleventh congress's political report by "creating foundations to turn the country into an effectively modern and industrialized country soon". The replacement of the deadline "by 2020 " with the vague term "soon" reflects the Party's more realistic view of the economy as well as its cautious assessment of the country's industrialization prospects. ${ }^{2}$

Among the reasons for Vietnam's failure to achieve the goal was its inability to grow a strong local manufacturing base and develop key strategic industries to provide a strong momentum for the country's industrialization. The automotive industry is one of the primary examples. Despite repeated efforts, Vietnam's automotive industry has been based

\footnotetext{
${ }^{1}$ Le Hong Hiep is a Fellow at the ISEAS - Yusof Ishak Institute, Singapore.

${ }^{2}$ Le Hong Hiep, "Vietnam in 2015: Challenges Persist amidst Hope for Change", in Southeast Asian Affairs 2016, edited by Malcolm Cook and Daljit Singh (Singapore: ISEAS - Yusof Ishak Institute, 2016), p. 365.
} 
mainly on a handful of assembling facilities, and supporting industries have remained largely undeveloped.

Recently, Vietnam's hopes for an indigenous automotive industry were rekindled when Vingroup, the country's largest private conglomerate, started in September 2017 the construction of a manufacturing complex in the northern city of Hai Phong and announced plans to develop a national car under the brand of Vinfast. Within a year, Vinfast managed to develop two prototypes, a sedan and a sport utility vehicle (SUV), which debutted with great fanfare at the 2018 Paris Motor Show. The company plans to put its first cars on the market in 2019.

While it is still too early to tell whether Vinfast will be successful, the way the company is rolling out its strategy, the great potential of the Vietnamese car market, the strong support that the Vietnamese government is lending the company, and the generally positive reception the Vietnamese public has shown for its first models, have all given rise to the hope that Vietnam will eventually be able to develop its own automotive industry. The impetus shown by Vinfast, if sustained, may also become a significant landmark along Vietnam's economic development and industrialization path.

This article reviews Vingroup's decision to enter the automotive industry and discusses its implications for Vietnam's industrialization drive in general and its automotive industry in particular. It will provide an overview of the Vietnamese automotive industry before examining Vinfast as a potential game changer. The article will then analyse the company's challenges and opportunities before offering some insights into the role that the company can play in Vietnam's industrialization process.

\section{AN OVERVIEW OF VIETNAM'S AUTOMOTIVE INDUSTRY}

Since Vietnam adopted market-based reforms in 1986, restructuring the economy towards a greater share of manufacturing in the GDP and an advanced high-tech industrial base has been a top priority for the country. The automotive industry with its sophisticated high-tech and industrial contents as well as the potential to generate spillover effects 
has therefore been one of the strategic industries that Vietnam would like to develop. In 2004, for example, the Vietnamese government considered the auto industry "a very important industry whose development should be prioritized". In the same vein, in 2007, the government classified the automotive industry as a "spearhead industry" (công nghiệp mũi nhọn). ${ }^{3}$

In 1991, a joint venture between Japanese and Korean investors and Vietnamese partners called Mekong Auto became the first car manufacturer in post-reform Vietnam. Its factory, completed in 1992, assembled cars under business cooperation contracts with Fiat and Ssangyong. However, it was not until the mid-1990s that Vietnam's automotive industry began to take clearer shape through joint ventures with foreign manufacturers such as Mitsubishi (1994), Toyota, Isuzu (1995), Ford and Hino (1996) to assemble vehicles under these brands for sale on the domestic market. They were later joined by other companies such as Honda (2005), Mercedes-Benz (2007), and GM (2011). Certain local companies, including Samco and Vinamotor, were also among the early players, but they mainly focused on assembling buses.

In 2004, a local company called Vinaxuki was established to manufacture and assemble cars and mini trucks under its own brand name as well as some Chinese brands. It even attempted to develop an indigenous sedan model but this eventually failed due to the lack of technology and capital, as well as poor planning and management. The company ceased operations in 2015.

Among the local auto companies, only Thaco (established 1997) and Thanh Cong (established 1999) have so far been successful. While Thaco is currently the largest contract manufacturer, assembler and distributor of automobiles in Vietnam for foreign brands such as Kia, Mazda and Peugeot, Thanh Cong is a large manufacturer, assembler and distributor of Hyundai passenger and commercial cars. However, even though Thaco and Thanh Cong are local companies rather than joint ventures, they

3 “20 Năm qua, DN Sản Xuất Lắp Ráp ô Tô Được 'Nuông Chiều' Đến Mức Nào?", CafeF, $2014<$ http://cafef.vn/vi-mo-dau-tu/20-nam-qua-dn-san-xuat-laprap-o-to-duoc-nuong-chieu-den-muc-nao-201408090205137633.chn>. 
mainly assemble cars with foreign brands. The added value that these two companies created and their impact on the indigenous automotive industry are therefore insignificant.

Even after almost twenty years of development, the automotive market of Vietnam remains very small. According to the Vietnam Automobile Manufacturers' Association (VAMA), 272,750 cars were sold by its members in Vietnam in 2017. Figure 1 shows the market share of VAMA members in 2016 and 2017.

The small size of the Vietnamese automotive market can be explained by several factors. During the 1990s and early 2000s, Vietnam was a rather poor country with low per capita income. As such, most Vietnamese people could not afford cars, and motorbikes therefore became their favoured means of transport. Moreover, during this period, the Vietnamese government virtually suspended the import of motor vehicles. According to Prime Minister's Decision No. 46/2001/QD-TTg dated 4 April 2001, used parts and used under-16-seater vehicles were prohibited from import; while new under-16-seater ready-made vehicles were only importable if licensed by the Ministry of Trade. Consequently, most automotive vehicles (except for some types of trucks and specialized vehicles) in the domestic market in the period 1991-2005 were sourced through foreign diplomatic missions and international organizations based in Vietnam. Only after the ASEAN Free Trade Agreement (AFTA) became effective for Vietnam and the country joined the WTO in 2007 did Vietnam begin to relax regulations on the importation of new and used cars. However, although quota limitations were removed, import tariffs remained high. Under Vietnam's WTO commitments, the average tariff on imported cars was gradually reduced but remained at 70 per cent by $2014 .{ }^{4}$ The high tariffs make cars largely unaffordable to most Vietnamese customers and further constrain the expansion of Vietnam's automotive market.

\footnotetext{
${ }^{4}$ Tuan Phan and Van Anh Thi Nguyen, "Impacts of the Protection Policy for Vietnam's Automobile Industry", 2008, pp. 7-8<https://mpra.ub.uni-muenchen. de/54067/1/MPRA_paper_54067.pdf>.
} 


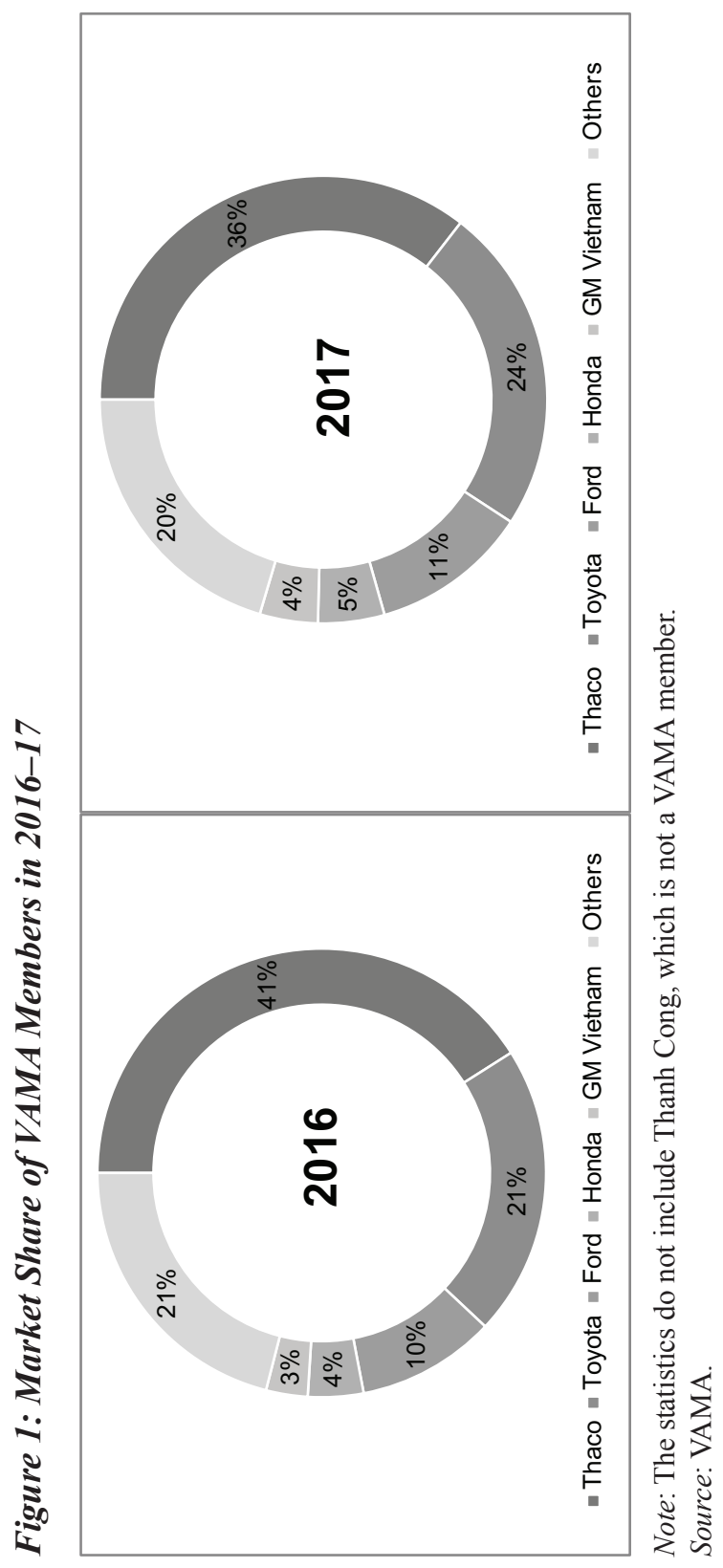


Another key feature of the Vietnamese automotive industry is the prevalence of assemblers at the expense of original manufacturers. Before the emergence of Vinfast, all the auto companies, be it foreign or local, mainly assemble vehicles from imported kits and were reluctant to localize their production. This was despite the fact that increasing the local content was a key requirement for these assemblers to enjoy various policy incentives and protection measures from the government over the past decades.

In 2002, the Vietnamese government announced the Strategy for Developing the Vietnamese Automotive Industry until 2010, with a vision toward 2020. ${ }^{5}$ The strategy laid an emphasis on increasing the local content of vehicles made in Vietnam. For example, it aimed to increase the localization ratio for passenger cars to 20-25 per cent by 2005 and 40-45 per cent by 2010 . However, Vietnam has failed to meet these targets. By 2016, for example, the average localization ratio of all vehicle types was just 7-10 per cent. Even the best performers in terms of localization, Thaco and Toyota, only reached $15-18$ per cent and 37 per cent, ${ }^{6}$ respectively, which are far below the targets set for 2010. Without localized production, Vietnam has not been able to turn the automotive industry into a "spearhead industry" that provides as strong a momentum for the country's industrialization as the Vietnamese government had expected.

Several obstacles prevented Vietnam from achieving the localization target. The most significant one is the limited size of the Vietnamese auto market. According to the Ministry of Industry and Trade (MOIT), in 2015, a total of 350,000 vehicles were sold in Vietnam. By 2016, the production capacity of automotive companies in Vietnam was 460,000

${ }^{5}$ This strategy has been superseded by the "Strategy for Developing the Vietnamese Automotive Industry until 2025, with a vision toward 2035" issued in 2014, which set rather similar goals.

${ }^{6}$ Toyota's localization rate of 37 per cent was for the Innova brand cars only. 
units, 200,000 of which were passenger cars. ${ }^{7}$ The limited market size and production capacity make it commercially unviable for automakers to localize their production. To be sure, Vietnam is a latecomer, and major automakers have already established their production hubs in neighbouring countries, especially Thailand and Indonesia, making it unnecessary for them to establish new manufacturing facilities in Vietnam. Spare part producers are not interested in investing in Vietnam either. Finally, under the ASEAN Free Trade Agreement (AFTA), import duties for completely built up (CBU) cars made in ASEAN countries were eliminated from the beginning of 2018. As such, instead of investing in new manufacturing facilities in Vietnam, most foreign automakers have found it more efficient to import cars assembled at their facilities in Thailand and Indonesia for sale on the Vietnamese market.

Given the above setbacks, it would be unrealistic for the Vietnamese government to rely on foreign automakers or joint ventures to bring about substantive changes to the automotive industry and to turn it into a key driver in the country's industrialization process. Against this backdrop, the participation of Vingroup in the automotive industry understandably attracted great attention from the Vietnamese public as well as its competitors.

\section{VINFAST: A GAME CHANGER?}

Vingroup is currently chaired by Pham Nhat Vuong, Vietnam's first selfmade billionaire with the net worth of US\$6.7 billion as of 25 December

\footnotetext{
${ }^{7}$ MOIT, “Chiến Lược Phát Triển Ngành ô Tô Việt Nam”, 2016 <http://www. moit.gov.vn/tin-chi-tiet/-/chi-tiet/chien-luoc-phat-trien-nganh-o-to-vietnam-108399-136.html>. According to another report of MOIT prepared by Japan International Cooperation Agency and Deloitte Tohmatsu Consulting in $2017,160,000$ automotive units were produced in Vietnam in 2016, compared to 1,920,000 units in Thailand and 1,070,000 units in Indonesia.
} 
$2018 .^{8}$ Vuong used to study geology in the Soviet Union. In 1993, Vuong and his friends set up in the Ukraine a company called Technocom, which Vingroup claims as its forerunner. Technocom quickly rose to success in the instant noodle industry and helped Vuong and his business partners accumulate a considerable amount of wealth. In the early 2000s, Vuong and his partners saw great business potential in Vietnam, especially in the real estate sector, and decided to return to the country to establish in 2002 a company that was later known as Vingroup.

Vingroup's main business is real estate development, which currently accounts for most of its revenue and profit. By acquiring large and welllocated land lots in major cities and developing projects within a short timeline but with reliable quality, Vingroup has earned a good reputation among homebuyers as well as local government authorities. This enabled the group to quickly expand its real estate business, which now includes residential, commercial, office and hospitality projects. Based on this success, the group has aggressively expanded into other businesses, such as retail, health care, education and agriculture, with the vision of establishing an ecosystem to support its real estate business. By 2017, Vingroup had become Vietnam's largest private conglomerate by revenue. In 2017, the company recorded VND89.35 trillion (approximately US $\$ 4$ billion) in revenue and VND5,655 billion (US\$254 million) in net profit. ${ }^{9}$

In a clear shift in its business strategy, Vingroup announced in 2017 that it would enter the automotive industry by setting up Vinfast, a wholly owned subsidiary, to build cars, buses and electric scooters for domestic as well as export markets. In 2018, Vingroup also entered the smartphone industry by setting up a subsidiary called Vinsmart to produce mobile

8 “Pham Nhat Vuong", Forbes, $2018<$ https://www.forbes.com/profile/phamnhat-vuong/\#77a65494382e>.

9 “LNST Năm 2017 Sau Kiểm Toán Của Vingroup Đạt 5.655 Tỷ Đồng, Tăng Trưởng 27\%”, CafeF, $2018<$ http://s.cafef.vn/vic-257240/lnst-nam-2017-saukiem-toan-cua-vingroup-dat-5655-ty-dong-tang-truong-27.chn>. 
devices based on technologies transferred from Spanish hardware firm BQ, of which Vingroup had acquired a 51 per cent stake. ${ }^{10}$ It also plans to produce smart TV and other home appliances. Vingroup also established VinTech to invest in IT technologies, including artificial intelligence and big data. Based on these strategic shifts, the group announced the goal of transforming itself into a tech company by $2028 .{ }^{11}$

Whether Vingroup can realize its ambitions remains uncertain, but the implementation of its automotive strategy has so far attracted much public attention and generated substantial debate. It is a huge investment (up to US $\$ 3.5$ billion) and can be a "maker" or "breaker" of Vingroup's commercial success in the future. If Vingroup's automotive business proves successful, it will turn the group into a manufacturing giant and facilitate its expansion into international markets. Moreover, it can also transform Vietnam's automotive industry in a meaningful way. According to the group's announcement, it aims to reach a production capacity of 500,000 cars and a localization ratio of 60 per cent by $2025 .{ }^{12}$

The pace of Vingroup's implementation of its automotive business strategy has also impressed observers. Within just more than one year after its ground-breaking ceremony in September 2017, Vinfast's manufacturing complex in Dinh Vu Economic Zone, Hai Phong, was completed and ready for production. With the total area of 335 hectares, it will be the third largest automotive manufacturing complex in the world, after Volkswagen's complex in Wolfsburg (650 hectares) and

\footnotetext{
${ }^{10}$ Nguyen Thi Bich Ngoc, "Vingroup Acquires 51\% of Spanish Hardware Firm BQ to Make Smartphones", Dealstreetasia, $2018<\mathrm{https} / /$ www.dealstreetasia. $\mathrm{com} /$ stories/vingroup-acquires-51-in-spanish-hardware-firm-bq-to-makesmartphones-113548/>.

11 “Vingroup Công Bố Chiến Lược Trở Thành Tập Đoàn Công Nghệ", VnExpress, $2018<$ https://vnexpress.net/kinh-doanh/vingroup-cong-bo-chien-luoc-trothanh-tap-doan-cong-nghe-3795859.html>.

12 ، ‘Trận Đánh’ 3,5 Tỷ USD Của Tỷ Phú Phạm Nhật Vượng Được Nhận Xét Như Thế Nào?", Soha, 2017 <http://soha.vn/tran-danh-35-ty-usd-cua-ty-phu-phamnhat-vuong-duoc-nhan-xet-nhu-the-nao-20170906135722122.htm>.
} 
Hyundai Motors' plant in Ulsan (502 hectares). ${ }^{13}$ In October 2018, Vinfast's first two prototypes, a sedan and an SUV, were introduced at the Paris Motor Show. In November 2018, a small car model called Fadil was also unveiled in Hanoi. The company plans to deliver its first cars to customers in 2019, while its electric scooter models under the brand Klara have already been available on the market since November 2018.

To accelerate its market participation, Vinfast has relied on partnerships with various foreign companies for designs, manufacturing equipment and components. For example, the designs of its first sedan and SUV models, the Lux A2.0 and Lux SA2.0, were done by Italdesign Giugiaro, while key technologies and manufacturing equipment were sourced from well-known partners, including BMW, Magna Steyr, Bosch, ZF, Siemens, Schuler, FFT, EBZ, Hirotec, ABB, Durr, GROB, Thyssenkrupp, MAG and Eisenmann. In order to achieve its localization ratio of 60 per cent, Vinfast has also worked with international suppliers to set up factories for parts and components in its complex in Hai Phong. In June 2018, Vinfast signed a Memorandum of Understanding (MoU) for a joint venture with Aapico Hitech Plc., one of Thailand's leading auto parts manufacturers, to build a press shop in its complex to supply Body in White (BIW) parts for Vinfast products. Vinfast plans to have eight parts factories set up in its complex, including four wholly owned by Vinfast, two joint ventures between Vinfast and suppliers, and two wholly owned by suppliers. ${ }^{14}$ At the same time, the company has also acquired GM's Vietnamese operations, including its Hanoi plant, dealer network and employee base. Vinfast's city car model Fadil was licensed from GM.

${ }^{13}$ Data from Popular Mechanics, cited in Duc Huy, "Nhà Máy VinFast - Điều Kỳ Lạ Giữa Vùng Biển", VnExpress, $2018<$ https://vnexpress.net/oto-xe-may/nhamay-vinfast-dieu-ky-la-giua-vung-bien-3816387.html >

${ }^{14}$ Bach Moc, "Vingroup Sẽ Dành 30\% Diện Tích Tổ Hợp VinFast Thành Lập Khu Nội Địa Hóa", Vietnambiz, 2018 <https://vietnambiz.vn/vingroup-se-danh30-dien-tich-to-hop-vinfast-thanh-lap-khu-noi-dia-hoa-53702.html> . 
Vinfast also has a vision for the future. In the initial phase, the company will develop cars using internal combustion engines, but it also plans to keep up with the trend of the industry by developing battery electric cars through its partnership with Germany's EDAG Engineering. ${ }^{15}$ In preparation for this future move, the company has successfully developed its first smart e-scooter models equipped with advanced features such as $3 \mathrm{G}$ Internet, GPS, remote locking and trip data synchronization. The company is planning to produce 250,000 e-scooters a year in the first phase. In the second phase, the capacity will be increased to 500,000 units each year and could eventually reach 1 million. ${ }^{16}$ If Vinfast is successful in winning customer confidence through its e-scooters products, it will be easier for the company to market its electric cars to the market later. Moreover, as e-scooters are more affordable than cars and at the same time superior to the millions of traditional motorbikes roaming Vietnamese streets, the e-scooter business can be a back-up option to offset financial risks for the company in case its car business does not take off as expected.

Vinfast's approach, which is based on its stated mission of becoming a leading automaker in Southeast Asia and building a world-class Vietnamese brand, has therefore generated new hope for Vietnam's national automotive industry. But how realistic is such hope?

\section{VINFAST'S CHALLENGES}

The most serious challenge for Vinfast is to compete with international giants in both domestic and foreign markets. The company emphasizes that it aims to win the confidence of customers by the quality of its

\footnotetext{
${ }^{15}$ James Pearson, “Fast and Serious: Vietnam's First Domestic Car Manufacturer Bets Big”, Reuters, $2018<$ https:/www.reuters.com/article/us-vingroupvietnam-autos/fast-and-serious-vietnams-first-domestic-car-manufacturer-betsbig-idUSKCN1MB1WN>.

16 "Vinfast Launches New E-Scooter", Vietnam News Agency, $2018<$ https:// en.vietnamplus.vn/vinfast-launches-new-escooter/141303.vnp>.
} 
products, which it seeks to ensure through application of advanced industry standards and cooperation with prestigious partners and suppliers. However, even if Vinfast looks to export its products, as a young brand with no proven track record, it will need to focus on the domestic market first, at least in the coming five to ten years. This was also acknowledged by Vinfast's CEO Jim Deluca. ${ }^{17}$

Nevertheless, even in the domestic market, Vingroup will have to work hard to sell its cars to customers who typically prefer Japanese brands and imported cars to domestic ones. As such, in the long run, whether Vinfast can produce quality cars with good prices will be the most important factor determining its commercial success.

In order to make its production more efficient, and to reduce car prices, Vingroup will need to increase its manufacturing scale. In this regard, the small size of the domestic market is a major impediment. As such, Vingroup and other domestic automakers may lobby the government to lower different types of fees and taxes, such as the special consumption tax on cars or import duties on car components, to make cars more affordable to Vietnamese customers. If the Vietnamese government decides to adopt these measures, car prices will drop. However, the government will need to offset the negative impact on tax revenue by increasing other relevant fees and taxes on car ownership and usage, which eventually may dishearten certain car buyers. At the same time, to change the country's traffic culture, reduce air pollution and grow the automotive market, the Vietnamese government is likely to consider gradually phasing out motorbikes in certain big cities, especially Hanoi and Ho Chi Minh City. However, this measure is not going to be feasible unless local governments provide alternative public transport options for those who cannot afford cars.

However, even if cars become more affordable to Vietnamese customers, the lack of infrastructure for cars is yet another challenge that not only Vinfast but also other automakers will have to face. Frequent traffic jams and the lack of parking spaces have long discouraged car

${ }^{17}$ Pearson, "Fast and Serious: Vietnam's First Domestic Car Manufacturer Bets Big". 
buyers in major cities. Although Vietnam's road system is improving through the participation of private investors under the Public-Private Partnership (PPP) model, Vietnam will need to build more highways within and between cities and reserve more urban spaces for parking facilities if it wants to give a boost to the automotive industry. However, given the government's budget constraints and the controversies over PPP infrastructure projects, it will likely take a long time for the Vietnamese infrastructure system for cars to be upgraded to levels comparable to those in neighbouring countries, such as Thailand and Malaysia.

Competition from imported cars will be another major challenge. Most Vietnamese car buyers would prefer imported cars over domestically produced ones. Even though Vinfast emphasizes its adoption of advanced international standards and the collaboration with world-class partners, certain Vietnamese customers may still hesitate about buying Vinfast products before the company has successfully built up its domestic record. To support Vinfast and domestic automakers, the Vietnamese government may try to adopt certain protectionist measures against imported cars. In fact, in a move designed to deal with the elimination of import tariffs on ASEAN cars, the Vietnamese government issued Decree No. 116/2017/ND-CP dated 17 October 2017 to introduce strict requirements for manufacturing, assembling and importing automotive vehicles and providing motor vehicle warranty and maintenance services in Vietnam. To implement Decree 116, the Ministry of Transport promulgated Circular No. 03/2018/TT-BGTVT three months later to provide for technical and environmental safety inspections of imported automotive vehicles. These two legislations created a lot of obstacles for car importers by increasing their administrative costs and prolonging import procedures, which effectively increased the price of imported cars. However, these measures did not prove to be as efficient as expected. Almost no cars were imported into Vietnam during the first quarter of 2018 due to these new regulations, but the number of imported cars gradually bounced back in subsequent months. Moreover, as Vietnam is now a member of the World Trade Organization and various free trade agreements, introducing protectionist measures, including technical barriers, will likely expose Vietnam to legal troubles and retaliation from other countries. 
Finally, Vinfast will have to invest heavily in R\&D capabilities and human resource development to internalize the imported technologies and know-hows. For example, Vinfast's engine shop was built completely by its contractor on a turnkey basis, and it has to rely on foreign suppliers for most other technologies and know-hows. Vinfast's technical teams are reportedly rather inexperienced and still unable to master these technologies, leading to their reliance on consultants, especially AVL. Vinfast will also need to work with partners to establish facilities for manufacturing car components and spare parts to achieve the expected localization ratio of 60 per cent. However, certain partners, especially those who are expected by Vinfast to wholly own the facilities, may be hesitant since the success of their investment in a new facility in Vietnam will depend heavily on Vinfast's future success — something that remains uncertain.

It may make business sense that Vinfast, in the initial stage, had to take a short cut by importing most of their technologies, know-hows, parts and components, but in the long run, failing to internalize these resources will cause the company to produce just another type of "Made in Vietnam" cars, and not the type of "Made by Vietnam" cars that the company wishes to develop. Meeting this target, however, will be another significant challenge due to both the large investment needed and the lack of a relevant technological base and of qualified human resources in Vietnam.

\section{VINFAST'S OPPORTUNITIES}

The challenges for Vinfast will be massive, but several factors may yet play in Vinfast's favour.

First, the potential for the Vietnamese automotive market remains ample. Currently, the car ownership ratio in Vietnam is 16 cars/1,000 residents, significant lower than that of Malaysia $(341 / 1,000)$, Thailand $(196 / 1,000)$, and Indonesia $(55 / 1,000) \cdot{ }^{18}$ At the same time, as a country of

\footnotetext{
${ }^{18}$ Data from Solidiance, cited in "Tỉ Lệ Người Việt Sở Hữu ô Tô Vẫn ở Mức Thấp", Thanh Nien, $2017<$ https://xe.thanhnien.vn/thi-truong-xe/ti-le-nguoiviet-so-huu-o-to-van-o-muc-thap-12561.html>.
} 
94 million people with young demographics and a fast expanding middle class, Vietnam is a promising market with significant sale opportunities for Vinfast and other automakers if they can cater to the varied demands of local customers. Meanwhile, although it will not be easy for Vinfast to expand internationally before it has built up its track record at home, the success story of rather latecomers on the international automotive market such as KIA and Hyundai suggests that Vinfast does stand a chance if it has the right business strategies to build quality cars with good prices.

Second, as a new player in the industry, Vinfast is no doubt facing many difficulties, but at the same time, it also enjoys certain benefits from being a latecomer. For example, the company can adopt new, advanced technological platforms or a forward-looking business strategy right from the beginning without having to deal with legacy issues. The company's decision to develop e-scooters and electric cars are cases in point. Moreover, although Vingroup has not had a track record in the automotive industry, it has a good track record in other businesses, especially property development, which was what enabled the company to raise funds from financial institutions and win the trust of its partners and suppliers in the first place.

Third, the sound business and financial performance of Vingroup over the years provides yet another strong foundation for the company to confidently take up the new challenge. Commenting on whether Vinfast is a risky gamble for Vingroup, President of the Vietnam Automotive Transport Association Nguyen Van Thanh observed that "It's only risky if Mr Vuong does not have money ... But Mr Vuong has money. He is now the richest man in Vietnam - if he does not dare to do the auto business, then nobody does". ${ }^{19}$ Although the comment sounds simplistic, it does reflect the popular belief among a large segment of the Vietnamese public that Vingroup is the best-positioned company to lead Vietnam's efforts in building up an indigenous automotive industry. Apart from having financial resources, the company's business ecosystem in different

19 “ 'Trận Đánh’ 3,5 Tỷ USD Của Tỷ Phú Phạm Nhật Vượng Được Nhận Xét Như Thế Nào?". 
sectors and its large customer base of about 5 million middle-class people provide the company with a unique advantage in marketing its automotive products in the domestic market. For example, it would not be a surprise if the company targets its homebuyers as the most potential customers of Vinfast. Meanwhile, with its diverse business ecosystem, the company can also provide promotion packages with additional benefits from its other businesses, such as health care or holiday vouchers, or even discounts for housing products, to lure new car buyers.

Fourth, Vingroup in general, and Vinfast in particular, enjoy strong political backing from Vietnamese government authorities. It is an open secret that Vingroup's success in the real estate business is significantly indebted to its political connections. These connections facilitated the group's acquisition of large, well-located land lots in major cities, mostly from state-owned enterprises, to develop its real estate projects, which gave Vingroup a considerable advantage over its competitors. Meanwhile, Vingroup's political connections and the alignment between Vinfast's commercial goals and the government's industrial policy objectives have turned Vinfast into a darling of Vietnamese politicians. For example, the company's manufacturing complex in Hai Phong has been visited by various high-ranking officials on multiple occasions during a short period of time. Specifically, Prime Minister Nguyen Xuan Phuc attended the ground-breaking ceremony of the complex in September 2017, visited the complex again in May 2018, and attended the debut ceremony of the company's first car models in Hanoi in November 2018. During his visit to the complex in May 2018, Mr Phuc praised Vinfast's efforts in developing the complex and its contribution to national development. $\mathrm{He}$ also asked central government ministries and the Hai Phong government to provide necessary support for Vinfast to be successful. ${ }^{20}$ In addition, CPV General Secretary Nguyen Phu Trong and National Assembly Chairwoman Nguyen Thi Kim Ngan also paid a visit to the complex

\footnotetext{
${ }^{20}$ Vu Dung, "Thủ Tướng Yêu Cầu Tạo Thuận Lợi Cho Thương Hiệu VinFast Thành Công", Voice of Vietnam, $2018<$ https://vov.vn/chinh-tri/thu-tuong-yeucau-tao-thuan-loi-cho-thuong-hieu-vinfast-thanh-cong-761839.vov>.
} 
in November 2017 and July 2018, respectively. The visit by Mr Trong was particularly noteworthy because as a Party leader, he rarely visits private enterprises. The visit therefore signifies that Vinfast has gained the special attention from Mr Trong and the Party.

Such strong political support and Vinfast's importance to the local economy have led the Vietnamese government to provide Vinfast with various preferential incentives. These include a 50 per cent reduction in corporate income tax (at 10 per cent instead of 20 per cent) for its first fifteen years of operation, a 50 per cent reduction in personal income tax for the company's staff, reduced or no rent for land and water surface usage, and several other incentives regarding customs duties, value-added tax, and special consumption tax for Vinfast's assets and production activities within its Hai Phong complex. ${ }^{21}$ Such policy incentives help the company reduce costs and navigate financial difficulties anticipated for its first years of operation.

Finally, nationalist sentiments can also play in Vinfast's favour in the domestic market. Right from the beginning, Vinfast wanted to mobilize nationalist sentiments as a means to connect with Vietnamese customers and to win government support. For instance, Vinfast deliberately held the ground-breaking ceremony of its Hai Phong complex on 2 September 2017, the national day of Vietnam. The way the company chose its brand name is also telling. According to the company's website, Vinfast stands for Vietnam, Phong cách (style), An toàn (safety), Sáng tạo (innovation), and Tien phong (pioneer). Obviously, Vinfast wants not only to relate its emergence to the rise of a developed and prosperous Vietnam, but also to capitalize on Vietnamese customers' pride in driving a modern and quality national car. Although such nationalist and patriotic feelings will not matter to all Vietnamese car buyers, it will nevertheless help Vinfast win certain customers, especially if its products have decent quality, good design and acceptable price.

${ }^{21}$ Bach Duong, "Rót Tỷ 'Đô' Vào Khu Kinh Tế Đình Vũ - Cát Hải, Vingroup Được Nhiều Uu Đãi”, VnEconomy, $2018<$ http://vneconomy.vn/doanhnhan/rot-ty-do-vao-khu-kinh-te-dinh-vu-cat-hai-vingroup-duoc-nhieu-uudai-20170905115148230.htm>. 


\section{CONCLUSION: VINFAST AND VIETNAM'S INDUSTRIALIZATION PROSPECTS}

Considered altogether, Vinfast's challenges seem to outweigh the advantages it enjoys. More importantly, Vinfast's advantages mainly exist in the domestic market. In the international market, it will have to build up its track record from scratch and compete against established rivals. Nevertheless, it can be argued that the emergence of Vinfast remains a positive development for not only Vietnam's automotive industry but also its industrialization ambitions.

As stated by Vinfast in its introduction: ${ }^{22}$

By participating in the automotive industry, which generates spillover effects, Vingroup wishes to play a part in the development of Vietnam's heavy industries and manufacturing base, and contribute to the country's modernization and industrialization.

The Vietnamese government is fully aware of the potential benefits of Vingroup's participation in the automotive industry. Speaking at the ground-breaking ceremony of Vinfast complex in September 2017, Prime Minister Nguyen Xuan Phuc noted: ${ }^{23}$

This project is of great significance as it creates 25,000 jobs, leads to the emergence of hundreds of suppliers in supporting industries, and in the future will contribute to government revenue an amount equivalent to the current total inland revenue of Hai Phong City ... The start-up of this project is a respectable act of patriotism.

22 Vinfast, "Về Chúng Tôi", $2018<$ https://vinfast.vn/ve-chung-toi.htm>. 23 “ ‘Trận Đánh’ 3,5 Tỷ USD Của Tỷ Phú Phạm Nhật Vượng Được Nhận Xét Như Thế Nào?". 
It is not a coincidence that the messages of Vinfast and Prime Minister Phuc share nationalistic overtones. For Vingroup, the message underlines its strategy to become a national tech company as well as its marketing tactic to woo domestic customers. For the Vietnamese government, both Vinfast and Vingroup's transformation into a tech company will bear heavily on the country's industrialization prospects.

At the national level, if Vinfast proves successful, it will provide a significant boost to the country's GDP growth and reinvent Vietnam's automotive industry. Meanwhile, the successful transformation of Vingroup into a tech company, in which Vinfast plays a critical role, influence more than just GDP statistics. The group's transformation from a resource-based real estate developer into an innovation-based high-tech manufacturer, if successful, will symbolize Vietnam's evolution from a resource- and labour-based economy into an advanced innovation-led and industrialized one. At the same time, Vingroup, a private conglomerate, playing a key role in developing the national automotive industry will further reinforce Vietnam's market-based economic reforms. The government will accordingly be further incentivized to champion private conglomerates in developing other critical industries.

It is too early to speculate about the success of Vingroup's strategy to become a tech company or about the commercial viability of Vinfast itself. Various challenges, both domestic and international, can obstruct the company from achieving its goals. The group's past successes provide no guarantee for Vinfast's prospects, as the automotive industry is a completely different game played on a different field with different players and a different set of rules, in which Vingroup has had no experience. In case Vingroup's bids falter, not only Vingroup but also the whole economy will suffer. The failure of Vinfast may cost Vingroup more than what it has won over the past two decades. Moreover, given Vingroup's deep roots in the economy, the large amount of debts that it has accumulated, as well as the more than 50,000 employees on its payroll, should the group land in trouble, the government will need to provide intensive and costly support to sustain it. More importantly, Vietnam's ambitions to develop an indigenous automotive industry to boost national industrialization will be hard hit. 